\title{
ANALISIS FAKTOR-FAKTOR YANG MEMPENGARUHI KEPUTUSAN PEMBELIAN ONLINE MAHASISWA DI KOTA MEDAN PADA APLIKASI SHOPEE
}

\author{
Wisnu Rayhan Adhitya \\ Fakultas Ekonomi dan Bisnis, Program Studi Manajemen, Universitas Potensi Utama,Jl. K.L.Yos Sudarso, Tj. \\ Mulia, Medan Deli, Kota Medan-20241 Telp: (061) 6640525 \\ wisnurayhanadhitya @gmail.com
}

\begin{abstract}
Abstrak
Permasalahan dalam penelitian ini adalah perubahan paradigma para Mahasiswa di Kota Medan dalam sikap berbelanja yang duulunya terbiasa secara konvensional atau tradisional sekarang sudah cenderung mengarah modern dengan menggunakan teknologi yang berkembang pesat saat ini. Perubahan paradigma belanja ini biasa disebut dengan online shopping yaitu melakukan kegiatan jual beli dengan menggunakan infrastruktur hardware, software dan jaringan internet dalam prosesnya. Tujuan penelitian ini adalah untuk mengetahui secara simultan dan parsial variabel kualitas produk, harga produk, kemudahan berbelanja dan ulasan produk terhadap keputusan pembelian online Mahasiswa di Kota Medan. Metode analisis data yang digunakan adalah deskriptif kuantitatif dengan menggunakan analisis regresi linier berganda. Variabel kualitas produk (XI) secara parsial berpengaruh positif dan signifikan terhadap keputusan pembelian (Y), harga produk (X2) secara parsial berpengaruh positif dan signifikan terhadap keputusan pembelian $(Y)$, kemudahan berbelanja (X3) secara parsial berpengaruh positif dan signifikan terhadap keputusan pembelian $(Y)$, ulasan produk (X4) secara parsialberpengaruh positif dan signifikan terhadap keputusan pembelian (Y), kualitas produk (X1), harga produk (X2), kemudahan berbelanja (X3), dan ulasan produk(X4) secara simultan berpengaruh positif dan signifikan terhadap keputusan pembelian $(Y)$ online mahasiswa di kota Medan pada aplikasi Shopee.
\end{abstract}

Kata kunci: Kualitas Produk, Harga Produk, Kemudahan Berbelanja Review Produk dan Keputusan Pembelian Online

\begin{abstract}
The problem in this study is the paradigm shift of the students in Medan City in their shopping attitude which used to be conventional or traditional, now they tend to be modern by using technology that is developing rapidly at this time. This change in shopping paradigm is commonly referred to as online shopping, which is conducting buying and selling activities using hardware, software and internet network infrastructure in the process. This study aims to determine simultaneously and partially the variables of product quality, product prices, convenience of shopping and product reviews on online purchasing decisions of students in Medan City. The data analysis method used is descriptive quantitative using multiple linear regression analysis. Product quality variable (X1) partially positive and significant effect on purchasing decisions $(Y)$, product price $(X 2)$ partially positive and significant effect on purchasing decisions (Y), ease of shopping (X3) partially positive and significant effect on decisions purchase (Y), product reviews (X4) partially positive and significant effect on purchasing decisions $(Y)$, product quality $(X 1)$, product prices (X2), ease of shopping (X3), and product reviews (X4) simultaneously affect positive and significant to the online purchasing decisions (Y) of students in the city of Medan on the Shopee application.
\end{abstract}

Keywords: Product Quality, Product Price, Ease of Shopping Product Reviews and Online Purchase Decision 
Wisnu Rayhan Adhitya, Analisis Faktor-Faktor Yang Mempengaruhi... 143

\section{PENDAHULUAN}

Sebagaimana yang kita tahu, saat ini kita hidup di Zaman dengan teknologi yang canggih, era digital. Dimana kita banyak menggunakan smartphone dan komputer dalam melakukan aktivitas. Dari mulai telepon, SMS, email, melihat segala berita sampai melakukan transaksi jual beli. Kebanyakan dari aktivitas kita, menggunakan media internet. Saat ini Revolusi Industri 4.0 akan dimulai. Semuanya akan menggunakan fasilitas dari internet. Revolusi industri itu sendiri artinya suatu perubahan dalam sumber daya manusia, menurunkan atau menghilangkan tenaga manusia di pekerjaan tersebut lalu melakukannya di pekerjaan lain. Revolusi Industri abad ini, yang telah berubah adalah fasilitas media internet yang berkembang pesat. Tidak dipungkiri, semua kalangan sudah memiliki gadget, dari yang tidak mengerti apa-apa hingga mengerti segalanya. Dan gadget atau smartphone tidak lepas dari koneksi internet. Alhasil peminat memakai pulsa juga menurun. Semuanya beralih ke internet.

Saat ini telah hadir sistem belanja Online. Belanja Online akan mempermudah kita dalam membeli suatu barang atau produk. Dan terkadang produk tersebut hanya ada di toko Online, atau konsumen ingin barang yang berkualitas tinggi (original) yang dikirim langsung dari luar negeri. Setiap konsumen memiliki kebutuhan dan keinginannya dalam berbelanja sesuai gaya hidup dan pendapatannya. Maka dari itu, telah disediakan cara mudah berbelanja Online, yaitu melalui situs Online Shop atau Market Place yang saat ini telah banyak hadir sesuai kebutuhan dan keinginan para konsumen. Ada sekitar 10 Market Place, dari mulai untuk kalangan atas hingga untuk kalangan menengah, dan saya memilih Shopee sebagai bahan penelitian saya.

Online Shop adalah tempat dimana kita melakukan kegiatan jual beli barang secara Online atau melalui media internet. Jadi kita tidak dapat bertemu langsung pada pemilik toko melainkan melalui pesan singkat. Untuk metode pembayarannya, dapat dilakukan melalui ATM(Transfer Bank), Card Credit, Alfamart/Indomaret, OneKlik, dan juga bisa Bayar di tempat. Sekarang, lebih banyak orang berbelanja Online daripada langsung ke toko. Dengan berbagai alasan, mulai dari malas mengantri, tidak mau ribet, dan sebagainya. Dengan hanya sekali klik dan transfer, barang sudah diantar ke rumah. Keuntungannya konsumen dapat melihat gambar atau produk dan melakukan pembelian dalam waktu 24 jam dan akan langsung diproses setelah transfer. Namun, ada juga marketplace yang menawarkan fitur "Bayar di Lokasi", yang melibatkan pembayaran saat pesanan telah dikirimkan oleh kurir.

Di era digital seperti sekarang ini, perkembangan teknologi dan informasi yang sangat cepat menyebabkan persaingan bisnis yang semakin ketat. Hal ini memacu produsen untuk berpikir lebih kritis, kreatif dan inovatif terhadap perubahan yang terjadi, baik di bidang sosial, budaya, politik maupun ekonomi. Hal terpenting yang harus dilakukan sebuah bisnis untuk berhasil dalam persaingan bisnis adalah berusaha dan membangun strategi bisnis untuk mencapai tujuan meningkatkan dan mempertahankan konsumen. Untuk mencapai hal tersebut, setiap bisnis harus berusaha untuk menghasilkan barang dan jasa yang memuaskan kebutuhan dan keinginan konsumen.

Seperti yang kita ketahui sebelumnya, seiring dengan perkembangan teknologi dan informasi, banyak bermunculan toko online dengan banyak jenis kelamin mulai dari remaja hingga dewasa. Produk yang ditawarkan juga beragam, mulai dari makanan, peralatan rumah tangga, gaya hidup, otomotif, elektronik dan lain-lain. Semua barang tersebut dijual secara online melalui website, akun media sosial dan toko online di berbagai pasar. Berdasarkan uraian di atas, kualitas produk, harga dan promosi memiliki daya tarik tersendiri bagi peneliti yang dapat mengetahui keputusan pembelian di marketplace Shopee.

Salah satu faktor yang membuat konsumen memilih untuk membeli adalah kualitas produk. Perusahaan harus memperhatikan kualitas dari produk yang dihasilkannya karena dengan meningkatkan kualitas maka reputasi perusahaan akan meningkat, sehingga perusahaan akan mempunyai posisi yang baik dimata pelanggan, walaupun tidak. pasar dunia. . Selain itu, melalui peningkatan kualitas produk, perusahaan juga akan berpeluang untuk menekan biaya, yang berarti 
akan dapat melaksanakan kegiatan produksinya secara efisien dan efektif. Jika produk yang dihasilkan memenuhi kebutuhan dan harapan pelanggan, jumlah produk cacat dapat ditekan seminimal mungkin (zero waste). Perusahaan juga dapat memperoleh loyalitas pelanggan jika meningkatkan kualitas produknya karena konsumen peduli dengan kualitas barang yang dihasilkan perusahaan. Mengembangkan teknologi di bidang pemasaran agar produknya tetap dikenal konsumen agar dapat menghasilkan minat masyarakat untuk membeli. Salah satu strategi yang dapat diterapkan untuk menarik konsumen adalah dengan menetapkan harga produk yang dapat merangsang respon pasar. Harga produk harus mendorong calon konsumen untuk menggunakan produk dan menjauh dari produk pesaing serupa.

Shopee adalah situs belanja online dengan permintaan tinggi untuk penggemar produk online, serta booth merchandising untuk produsen yang menjual produknya. Produsen bisa menjual produknya dengan mudah, mempromosikan produknya juga mudah. Hal yang hebat tentang Shopee adalah ia menawarkan pengiriman gratis (ongkir) tanpa minimum pembelian, menawarkan cashback hingga 90\%. Dari perilaku konsumen saat berbelanja, layanan Shopee cukup membuat konsumen tertarik untuk melakukan pembelian di Shopee. Gaya hidup juga menjadi faktor. Ada banyak faktor yang berbeda mengenai preferensi pembelian konsumen saat berbelanja di Shopee, dan di penelitian saya ini akan membahas tentang faktor yang mempengaruhi keputusan konsumen yaitu mahasiswa yang berbelanja di Shopee.

\section{Rumusan Masalah}

Berdasarkan latar belakang masalah yang diuraikan sebelumnya, maka dirumuskan masalah penelitian dalam bentuk pertanyaan, yaitu:

1. Apakah kualitas produk secara parsial memliki pengaruh terhadap keputusan pembelian online Mahasiswa di Kota Medan pada aplikasi Shopee?

2. Apakah harga produk secara parsial memliki pengaruh terhadap keputusan pembelian online Mahasiswa di Kota Medan pada aplikasi Shopee ?

3. Apakah kemudahan berbelanja secara parsial memliki pengaruh terhadap keputusan pembelian online Mahasiswa di Kota Medan pada aplikasi Shopee ?

4. Apakah ulasan produk secara parsial memliki pengaruh terhadap keputusan pembelian online Mahasiswa di Kota Medan pada aplikasi Shopee ?

5. Apakah seluruh faktor-faktor secara simultan memliki pengaruh terhadap keputusan pembelian online Mahasiswa di Kota Medan pada aplikasi Shopee ?

\section{Tujuan Penelitian}

Berdasarkan pemaparan di atas, maka tujuan dilaksanakan penelitian ini adalah sebagai berikut:

1. Untuk mengetahui dan menganalisis kualitas produk memiliki pengaruh atai tidak secara parsial terhadap keputusan pembelian online Mahasiswa di Kota Medan pada aplikasi Shopee.

2. Untuk mengetahui dan menganalisis harga produk memiliki pengaruh atau tidak secara parsial terhadap keputusan pembelian online Mahasiswa di Kota Medan pada aplikasi Shopee.

3. Untuk mengetahui dan menganalisis kemudahan berbelanja memiliki pengaruh atau tidak secara parsial terhadap keputusan pembelian online Mahasiswa di Kota Medan pada aplikasi Shopee.

4. Untuk mengetahui dan menganalisis ulasan produk memiliki pengaruh atai tidak secara parsial terhadap keputusan pembelian online Mahasiswa di Kota Medan pada aplikasi Shopee.

5. Untuk mengetahui dan menganalisis seluruh faktor-faktor memiliki pengaruh atau tidak secara simultan terhadap keputusan pembelian online Mahasiswa di Kota Medan pada aplikasi Shopee. 
Wisnu Rayhan Adhitya, Analisis Faktor-Faktor Yang Mempengaruhi... 145

\section{Manfaat Penelitian}

Manfaat yang diharapkan peneliti dengan adanya penelitian ini adalah:

1. Hasil penelitian ini diharapkan dapat digunakan oleh perusahaan dalam mengambil dan melakukan suatu kebijakan dimasa yang akan datang yang bersifat lebih baik lagi.

2. Sebagai bahan referensi yang dapat menjadi bahan perbandingan dalam melakukan penelitian di masa mendatang, khususnya penelitian yang berkaitan dengan kajian ilmu e-commerce, e-business dan e-marketing

\section{LANDASAN TEORI}

\section{Pengertian Kualitas Produk}

Menurut Kotler (2010) Produk adalah segala sesuatu yang ditawarkan pasar untuk memuaskan kebutuhan dan keinginan pelanggan. Menurut Rambat Lupiyoadi (2001) produk adalah keseluruhan konsep dari suatu objek atau proses yang memberikan nilai tertentu kepada pelanggan. Menurut Tjiptono (2008) Produk adalah segala sesuatu yang dapat ditawarkan oleh produsen ke pasar untuk mendapatkan perhatian, penyelidikan, penelitian, pembelian, penggunaan, atau konsumsi untuk memenuhi kebutuhan atau keinginan pasar. Dari beberapa definisi di atas, dapat disimpulkan bahwa produk adalah suatu bentuk barang atau jasa yang dihasilkan oleh seseorang atau suatu badan usaha yang mempunyai nilai guna dan dipasarkan untuk memenuhi kebutuhan dan keinginan konsumen..

Menurut Tjiptono (2008) Kualitas produk adalah penilaian konsumen atas manfaat atau karakteristik produk. Menurut Kotler dan Armstrong (2014) yang menyatakan bahwa kualitas produk adalah kemampuan suatu produk untuk menjalankan fungsinya, yang dalam hal ini meliputi keseluruhan daya tahan, keandalan, akurasi, kemudahan penggunaan dan perbaikan produk, serta atribut produk lainnya. Jika suatu produk dapat menjalankan fungsinya, maka dapat dikatakan produk tersebut berkualitas baik. Menurut Kotler (2010) Sebagian besar produk termasuk dalam salah satu dari empat kategori kualitas, yaitu: kualitas buruk, kualitas sedang, kualitas baik, dan kualitas sangat baik. Beberapa atribut yang disebutkan di atas dapat diukur secara objektif. Namun, dari perspektif pemasaran, kualitas harus diukur dengan persepsi pembeli terhadap kualitas produk. Semakin berkembangnya bisnis maka kualitas produk juga menentukan perkembangan bisnis tersebut. Jika kondisi pemasaran membuat persaingan semakin ketat dan seiring dengan perkembangan perusahaan maka kualitas produk akan semakin besar. Selain itu, konsumen akan cenderung memilih produk dengan kualitas terbaik, kinerja terbaik, dan atribut inovatif.

Kualitas dari sudut pandang konsumen adalah sesuatu yang memiliki arti tersendiri dan berbeda dari sudut pandang produsen ketika memasarkan suatu produk yang dikenal kualitasnya. Kualitas produk merupakan hal utama yang harus diperhatikan oleh setiap perusahaan jika ingin produknya mampu bersaing di pasar. Konsumen selalu menginginkan produk yang berkualitas. Jika Anda dapat memuaskan ini, Anda dapat memuaskan pelanggan Anda dan meningkatkan jumlah konsumen. Hal tersebut sama dengan yang dijelaskan oleh Kotler dan Armstrong (2014) bahwa jika suatu perusahaan terus berupaya untuk meningkatkan kualitas produknya maka akan dapat memuaskan konsumen dan menambah jumlah konsumen.

Menurut Sofjan Assauri (2009) hal-hal yang dapat mempengaruhi secara langsung kualitas produk disebut dengan Sembilan bidang dasar atau 9M, yaitu :

a. Market (Pasar) Jumlah produk berkualitas yang dipasarkan oleh seseorang atau bisnis terus tumbuh pada tingkat yang eksplosif. Konsumen didorong untuk percaya bahwa ada produk yang dapat memenuhi sebagian besar kebutuhan mereka. Konsumen saat ini menginginkan dan mendapatkan produk yang lebih baik untuk memenuhi kebutuhan mereka. Cakupan pasar yang luas dan spesialisasi fungsional untuk produk yang ditawarkan. Dengan bertambahnya jumlah perusahaan, pasar berkembang menuju standar internasional. Terakhir, perusahaan harus mampu beradaptasi dengan cepat dengan kondisi yang ada. 
b. Money (Uang) Meningkatnya persaingan di sektor-sektor karena ekonomi global berfluktuasi telah mengakibatkan selisih keuntungan yang lebih rendah. Pada saat yang sama, kebutuhan akan otomatisasi dan loyalitas strategis telah menyebabkan biaya tinggi untuk proses dan peralatan baru. Peningkatan investasi di pabrik, dibayar dengan peningkatan produktivitas, mengakibatkan kerugian yang signifikan dalam produksi, hal ini karena perkiraan yang sangat parah dan serius. Fakta ini menarik perhatian para manajer di bidang penilaian biaya kualitas sebagai salah satu "kelemahan" dimana biaya operasional dan kerugian dapat ditekan untuk meningkatkan profitabilitas.

c. Management (Manajemen) Tanggung jawab untuk kualitas telah dibagikan ke beberapa kelompok ahli. Pada titik ini, departemen pemasaran dengan fungsi perencanaan produknya harus dapat menentukan persyaratan produk. Bagian perancangan bertanggung jawab untuk menciptakan suatu produk yang dapat memenuhi persyaratan ini. Departemen manufaktur mengembangkan dan meningkatkan proses sehingga dapat menyediakan kapasitas yang cukup untuk menciptakan produk yang memenuhi spesifikasi desain. Bagian pengendalian mutu merencanakan langkah-langkah mutu sepanjang proses yang mampu memastikan bahwa hasil akhir produk dapat memenuhi persyaratan mutu dan mutu pelayanan, begitu produk jadi, produk sampai ke tangan konsumen, menjadi bagian terpenting dari keseluruhan produk. . Hal ini semakin mempersulit manajemen puncak untuk menetapkan tanggung jawab yang sesuai untuk menilai penyimpangan dari standar kualitas..

d. Man (Manusia) Pesatnya perkembangan ilmu-ilmu pengetahuan dan teknologi dan pengenalan semua bidang baru seperti elektronik komputer, menciptakan permintaan yang tinggi untuk karyawan dengan pengetahuan khusus. Pada saat yang bersamaan, kondisi ini dapat menciptakan kebutuhan akan spesialis sistem teknis yang akan menyatukan semua bidang khusus untuk merencanakan, membangun, dan mengoperasikan berbagai sistem yang akan menghasilkan hasil yang diinginkan.

e. Motivation (Motivasi) Penelitian tentang motivasi manusia menunjukkan bahwa untuk mendapatkan imbalan dalam bentuk gaji tambahan, pekerja saat ini membutuhkan sesuatu yang dapat memperkuat rasa pencapaian mereka dan pengakuan yang mereka berikan secara pribadi, mereka menempatkan nilai tinggi pada pencapaian tujuan bisnis. Ini mengarah pada permintaan yang belum pernah terjadi sebelumnya untuk pendidikan berkualitas dan komunikasi yang lebih baik tentang kesadaran kualitas.

f. Material (Bahan) Karena biaya produksi serta persyaratan kualitas, para insinyur memutuskan untuk memilih bahan dengan batasan yang lebih ketat daripada di masa lalu. Alhasil, spesifikasi material menjadi lebih ketat dan variasi material menjadi lebih besar.

g. Machine and Mecanization (Mesin dan Mekanik) Kebutuhan perusahaan untuk dapat menekan biaya higga volume produksi dengan tujuan memuaskan konsumen membuat penggunaan beberapa peralatan pabrik menjadi lebih sulit dan bergantung pada kualitas bahan input mesin. Kualitas yang baik merupakan faktor penentu dalam menjaga waktu kerja mesin agar peralatan yang ada di dalamnya dapat digunakan dengan benar.

h. Modern Information Metode (Metode Informasi Modern) Perkembangan teknologi komputer membuka kemungkinan pengumpulan, penyimpanan, pengambilan dan pengolahan informasi dalam skala yang tidak terbayangkan sebelumnya. Teknologi informasi saat ini menyediakan cara untuk mengontrol mesin dan proses selama produksi serta mengontrol produk bahkan setelah produk sampai ke pelanggan. Metode pemrosesan data yang baru dan konsisten menciptakan kemampuan untuk mengelola informasi yang berguna, akurat, tepat waktu, dan prediktif yang mendukung keputusan yang membentuk masa depan bisnis.

i. Mounting Product Requirement (Persyaratan Proses Produksi) Kemajuan pesat dalam desain produk memerlukan kontrol yang lebih ketat atas seluruh proses pembuatan produk. Meningkatkan persyaratan kinerja untuk suatu produk menekankan pentingnya keamanan dan daya tahan produk.

Menurut Tjiptono (2008) terdapat beberapa dimensi yang mempengaruhi kualitas produk, diantaranya 
sebagai berikut :

a. Kinerja (performance) hal Ini berkaitan dengan aspek fungsional produk dan merupakan manfaat terpenting yang harus dipertimbangkan pelanggan sebelum membeli produk.

b. Keistimewaan Tambahan (Features) Yaitu performa produk yang berfungsi untuk menambah daya tarik produk itu sendiri. Dimensi fitur merupakan karakteristik tambahan yang melengkapi manfaat dasar suatu produk. Apabila manfaat utama suatu produk sudah standar, maka fitur perlu ditambahkan untuk menambah kualitas produk.

c. Kehandalan (Reliability) Probabilitas atau kemungkinan bahwa suatu produk dapat berfungsi atau tidak sesuai dengan standar dan keberhasilan fungsinya selama digunakan untuk jangka waktu tertentu dan dalam kondisi tertentu peristiwa tertentu. Semakin kecil kondisi kerusakan, semakin tinggi kualitas produk.

d. Kesesuaian Spesifikasi (Conformance) Hal tersebut berhubungan dengan kesamaan suatu produk dengan produk yang ditawarkan sebelumnya untuk dapat memenuhi kebutuhan konsumen dan tidak termasuk dalam cacat produk.

e. Daya tahan (Durability) Secara khusus, usia suatu produk sebagai ukuran daya tahan atau umur panjangnya. Semakin sering produk digunakan, semakin besar daya tahan produk.

f. Estetika (Ashtetics) Karakteristik tentang nilai-nilai estetika yang berhubungan dengan penampilan/display suatu produk untuk dilihat, aroma, rasa dan bentuk produk.

\section{Pengertian Harga Produk}

Harga merupakan salah satu variabel pemasaran yang harus diperhatikan oleh manajemen perusahaan, karena harga secara langsung dapat mempengaruhi volume penjualan dan profitabilitas perusahaan. Menurut William J. Stanton dalam Marius (2009), harga adalah kuantitas (mungkin ditambah beberapa baik) yang diperlukan untuk mendapatkan kombinasi dari produk dan layanan yang dimilikinya. Menurut Kotler dan Armstrong (2014), harga menentukan jumlah yang dibutuhkan untuk mendapatkan suatu produk atau jasa. Secara historis, harga telah menjadi faktor utama yang mempengaruhi pilihan pembeli. Dalam buku mereka, Kotler dan Armstrong menyebutkan bahwa penetapan harga adalah bagian terpenting dan kompleks dalam mengelola pemasaran. Di satu sisi, harga merupakan elemen strategis yang sangat penting, penting dalam bauran pemasaran karena menjelaskan persepsi kualitas, dan karena merupakan kontributor penting untuk positioning produk. Harga adalah satuan uang yang dipertukarkan untuk mendapatkan manfaat dari suatu produk atau jasa. Abdullah (Kotler, 2010) Harga adalah nilai total yang ditukarkan konsumen atau manfaat dari memiliki atau menggunakan suatu produk/jasa. Sementara Istijanto (2009) menunjukkan bahwa harga adalah jumlah yang dibayar konsumen untuk memperoleh pelayanan yang diinginkan dengan membandingkan biaya dan manfaat (cost and benefit to consumer).

Agar berhasil dalam memasarkan suatu produk atau jasa, setiap bisnis harus menetapkan harga yang tepat. Harga adalah satu-satunya elemen bauran pemasaran yang menghasilkan pendapatan atau pendapatan bagi bisnis, sedangkan tiga lainnya (produk, distribusi, dan promosi) menghasilkan biaya (biaya). Selain itu, penetapan harga adalah bagian dari bauran pemasaran yang fleksibel, yang berarti dapat berubah dengan cepat. Hal ini berbeda dengan karakteristik produk atau komitmen pada saluran distribusi. Kedua hal ini tidak dapat diubah/disesuaikan dengan mudah dan cepat, karena seringkali melibatkan keputusan jangka panjang.

Menurut Christopher dan Lauren (2007), konsep nilai ditinjau dari nilai konsumen dapat dikelompokkan menjadi empat, yaitu:

a. Value is low Prince. Sekelompok konsumen berpikir bahwa harga rendah adalah yang paling penting sedangkan kualitas adalah nilai yang kurang penting.

b. Value is whatever I want in a product or Services. Bagi konsumen dalam kelompok ini, nilai tidak hanya didefinisikan sebagai manfaat atau kualitas yang dapat diterima, tetapi juga sesuatu yang dapat memuaskan suatu keinginan

c. Value is the quality I get for the price I Buy. Konsumen dalam kelompok ini memiliki persepsi bahwa nilai adalah manfaat atau kualitas yang diterima tergantung dari harga yang dibayarkan. 
d. Value is what I get for what I give. Dalam kelompok ini, konsumen menentukan nilai berdasarkan jumlah manfaat yang diterima versus pengorbanan uang, waktu, dan tenaga.

Berdasarkan beberapa definisi di atas, dapat disimpulkan bahwa harga adalah jumlah yang harus dibayar pembeli untuk mendapatkan produk. Harga juga memiliki indikator dalam penelitian ilmiah yang digunakan oleh perusahaan dalam proses ini. Beberapa indikatornya (Kotler dan Amstrong, 2014) adalah sebagai berikut:

a. Keterjangkauan harga

b. Daya saing harga

c. Kesesuaian harga dengan kualitas produk

d. Kesesuaian harga dengan manfaat

\section{Pengertian Kemudahan Berbelanja}

Kenyamanan adalah sejauh mana seseorang dapat menggunakan apa pun yang mereka lakukan dengan mudah dan tanpa banyak usaha dalam prosesnya. Kemudahan penggunaan juga didefinisikan sebagai sejauh mana seseorang percaya bahwa menggunakan teknologi akan mudah. (Jogiyanto, 2007). Dari definisi tersebut dapat dilihat bahwa kemudahan penggunaan juga merupakan keyakinan tentang proses pengambilan keputusan. Jika seseorang percaya bahwa suatu sistem informasi mudah digunakan, mereka akan menggunakannya. Sebaliknya, jika seseorang menganggap sistem informasi tidak mudah digunakan, mereka tidak akan menggunakannya. Ada empat metrik kegunaan di aplikasi/situs web menurut Aladwani (2002) diantaranya :

a. Kemudahan untuk Mengenali. Kemudahan untuk mencari, menemukan dan mengakses aplikasi/website

b. Kemudahan dalam Navigasi. Kemudahan untuk bergerak di satu halaman maupun berpindah ke halaman lain di aplikasi/website

c. Kemudahan untuk Mengumpulkan Informasi. Kemudahan untuk mengumpulkan informasi mengenai harga, produk atau layanan di aplikasi/website

d. Kemudahan untuk Membeli. Kemudahan untuk mengisi format pembelian produk, membeli produk, dan membatalkan pembelian pada aplikasi/website

Kemudahan penggunaan didefinisikan sebagai keyakinan individu bahwa jika mereka menggunakan sistem tertentu, mereka tidak akan berusaha. Jadi jika seseorang menganggap suatu teknologi mudah digunakan, maka orang tersebut akan menggunakannya. Jadi variabel kenyamanan ini menunjukkan sistem yang tidak dirancang untuk mempersulit pengguna, tetapi yang dirancang dengan tujuan memberikan kenyamanan kepada pengguna. Jadi, seseorang yang menggunakan sistem tertentu akan bekerja lebih mudah daripada orang yang bekerja secara manual. Beberapa penelitian sebelumnya telah menunjukkan bahwa persepsi kemudahan penggunaan mempengaruhi sikap terhadap penggunaan teknologi.

Davis et.al.dalam Hardiawan (2013) mendefinisikan kenyamanan sebagai sejauh mana teknologi komputer dianggap relatif mudah untuk dipahami dan digunakan. Faktor kenyamanan ini ada hubungannya dengan cara transaksi bekerja secara online. Kenyamanan adalah hal terpenting yang perlu diperhatikan oleh vendor atau penjual online. Kenyamanan ini bisa jadi kadarnya berbedabeda tergantung pengguna atau pembeli itu sendiri, tapi tentunya pada dasarnya ada standar kenyamanan yang sama untuk semua pengguna. Belanja online pada umumnya dibandingkan dengan belanja offline, apa yang ditawarkan dalam belanja online seringkali harus lebih baik dari apa yang ditawarkan dalam belanja offline, kenyamanan sering menjadi salah satu poin penghasilan. Dari akses mudah ke pemilihan produk, pembelian mudah, pembayaran mudah hingga pengambilan atau pengiriman yang mudah. Internet yang memungkinkan akses toko dari mana saja adalah contoh sederhana dari kemudahan yang ditawarkan vendor e-commerce, kini calon pembeli dapat mengakses toko dari mana saja melalui komputer, laptop, PC atau perangkat mobile, baik smartphone maupun tablet.

Keputusan pembelian tidak perlu lagi dilakukan di dalam toko saat melihat barang dagangan, pengguna dapat melihat barang dagangan sambil menunggu di kedai kopi dan kemudian 
memutuskan untuk membeli ketika tiba di tempat tujuan lain. Proses checkout juga harus disederhanakan, yang berarti calon pelanggan memiliki fasilitas pembayaran dan alur metode yang menjadikan kenyamanan berbelanja sebagai prioritas utama. Hal ini dapat mempengaruhi pilihan metode pembayaran, dari transfer bank, kartu debit, kartu kredit atau metode pembayaran lainnya. Mungkin juga toko online atau penyedia layanan e-commerce tidak menawarkan berbagai metode pembayaran dari toko mereka, tetapi seiring dengan pertumbuhan konsumen dan kebutuhan mereka, mungkin nanti semua metode pembayaran tersedia di layanan e-commerce.

Kenyamanan adalah hal terpenting yang perlu diperhatikan oleh vendor atau penjual online. Kenyamanan itulah yang dapat mempermudah dan mempercepat bisnis. Davis et. al. dalam Hardiawan (2013) mendefinisikan bahwa Kemudahan penggunaan adalah sejauh mana teknologi komputer dianggap relatif mudah untuk dipahami dan digunakan. Faktor kenyamanan ini ada hubungannya dengan cara transaksi bekerja secara online. Kenyamanan merupakan hal terpenting yang perlu diperhatikan oleh pemasok atau penjual online agar konsumen dapat dengan mudah mengakses dan menggunakan website toko online untuk berbelanja.

\section{Pengertian Ulasan Produk}

Ulasan online adalah jenis informasi produk yang dibuat oleh orang-orang yang telah menggunakan produk (Yubo dan Jinhong, 2008). Ulasan produk online yang dibuat pengguna memiliki dampak penting pada keputusan pembelian seseorang (Walsh et al., 2004). Perusahaan seperti Amazon.com, menyediakan tempat untuk memberikan review produk yang dibeli melalui Amazon.com. Ada juga media lain yang hanya bisa memberikan rating dan review, misalnya Epinions, TripAdvisor, Yelp! dan Zagat. Pelanggan dapat menggunakan ulasan ini sebagai informasi untuk mendukung keputusan pembelian mereka (Lempert, 2006). Ulasan dapat membantu pelanggan menentukan kriteria ulasan produk dan mengurangi biaya yang dirasakan saat membuat keputusan pembelian. (Liu et al., 2011). Liu et al. (2011) mengatakan bahwa ulasan produk online dapat membantu pelanggan memahami produk, menetapkan kriteria ulasan produk, membuat keputusan yang tepat, dan mengurangi biaya yang dirasakan saat membuat keputusan.

Review produk adalah fitur yang terdapat dalam aplikasi/website yang digunakan untuk menjelaskan kelebihan atau kekurangan suatu produk. Ada empat indikator evaluasi produk (Lackermair, Kailer dan Kanmaz, 2013), diantaranya :

a. Kesadaran atau Awareness. Pembeli mengetahui fungsi peringkat produk di aplikasi/situs web dan menggunakan informasi ini dalam proses pemilihan.

b. Frekuensi atau Frequency. Pembeli sering menggunakan peringkat produk di aplikasi/situs web sebagai sumber informasi

c. Perbandingan atau Comparison. Sebelum membeli, pembeli membaca ulasan produk yang akan dibeli, yang terdapat pada aplikasi/website satu demi satu dan membandingkan ulasan-ulasan tersebut

d. Pengaruh atau Effect. Fitur ulasan produk di aplikasi/website memberikan pengaruh terhadap seleksi produk.

Selain itu menurut Sutanto dan Aprianingsih (2016) online consumer review merupakan bentuk dari mulut ke mulut elektronik dan dapat dilihat sebagai bentuk komunikasi pemasaran yang baru dan dapat mempengaruhi dan berperan dalam proses keputusan pembelian. Informasi yang diperoleh dari review konsumen online dapat digunakan untuk mengidentifikasi dan menilai produk yang dibutuhkan konsumen. Adanya rekomendasi atau pendapat (word of mouth) dari konsumen lain, seperti di platform sharing review atau komunitas, dapat mempengaruhi preferensi pembelian konsumen yang digunakan (Jalilvand, 2012). Thurau, Gwinner, Walsh, dan Gremler (2004) definisi dari mulut ke mulut sebagai pernyataan positif atau negatif oleh pelanggan potensial, pelanggan atau pelanggan saat ini tentang produk atau perusahaan yang informasi ini tersedia untuk banyak orang dan organisasi melalui Internet. Kietzman dan Canhoto (2013) menyatakan e-word to mouth adalah pernyataan atau pendapat konsumen tentang produk, layanan, merek atau bisnis yang dibagikan dengan konsumen lain melalui Internet. Preferensi pembelian konsumen adalah kegiatan individu 
yang berhubungan langsung dengan pembelian dan penggunaan barang dan jasa, termasuk proses pengambilan keputusan dalam penyusunan dan identifikasi kegiatan tersebut, oleh karena itu konsumen akan cenderung membeli suatu merek atau mengukur tindakan pembelian. sejauh daya beli konsumen dimotivasi oleh insentif tertentu.

\section{Pengertian Ulasan Produk}

Menurut Schiffman dan Kanuk dalam Etta (2013) Definisi keputusan adalah pemilihan tindakan dari dua atau lebih alternatif. Setiadi dalam Etta mendefinisikan bahwa inti pengambilan keputusan pembeli adalah proses integratif yang menggabungkan pengetahuan untuk mengevaluasi dua atau lebih perilaku alternatif dan memilih salah satunya. Keputusan pembelian menurut Tjiptono (2008) adalah proses di mana pembeli mengetahui suatu masalah, mencari informasi tentang produk atau merek tertentu, dan mengevaluasi beberapa alternatif yang digunakan untuk memecahkan masalah, yang kemudian mengarah pada keputusan pembelian. Menurut Kotler (2010) keputusan pembelian merupakan tahapan yang dilakukan oleh konsumen sebelum melakukan keputusan pembelian suatu produk.

Kotler dan Amstrong (2014) menunjukkan bahwa keputusan pembelian adalah keputusan pembeli tentang merek mana yang akan dibeli. Dalam keputusan pembelian terdapat dua faktor yang mengganggu antara niat untuk membeli dan keputusan untuk membeli Menurut Kotler dan Amstrong (2014) terdapat lima tahap yang dilalui konsumen dalam proses pengambilan keputusan pembelian, antara lain:

a. Presentasi kebutuhan. Langkah pertama dalam proses kebutuhan pembeli, di mana konsumen mengenali masalah atau kebutuhan.

b. Pencarian informasi. Tahap proses keputusan pembelian dimana konsumen ingin mencari informasi lebih banyak, konsumen mungkin hanya memperbesar perhatian atau melakukan pencarian informasi secara aktif.

c. Evaluasi alternatif. Tahap proses keputusan pembelian dimana konsumen menggunakan informasi untuk mengevaluasi merek alternatif dalam sekelompok pilihan.

d. Keputusan pembelian. Keputusan pembeli tentang merek mana yang dibeli.

e. Perilaku pasca pembelian. Tahap proses keputusan pembelian di mana konsumen mengambil tindakan selanjutnya setelah pembelian, berdasarkan kepuasan atau ketidakpuasan mereka.

Keputusan pembelian adalah proses menentukan pilihan konsumen dari berbagai alternatif produk yang paling sesuai dengan kebutuhan yang diinginkan. Dari definisi di atas dapat diketahui bahwa keputusan pembelian merupakan salah satu bentuk perilaku konsumen dalam menggunakan suatu produk. Dengan menggunakan suatu produk untuk membuat keputusan pembelian, konsumen melalui proses menggambarkan perilaku konsumen, menganalisis pilihan yang berbeda untuk membuat keputusan pembelian. 


\section{Kerangka Konseptual}

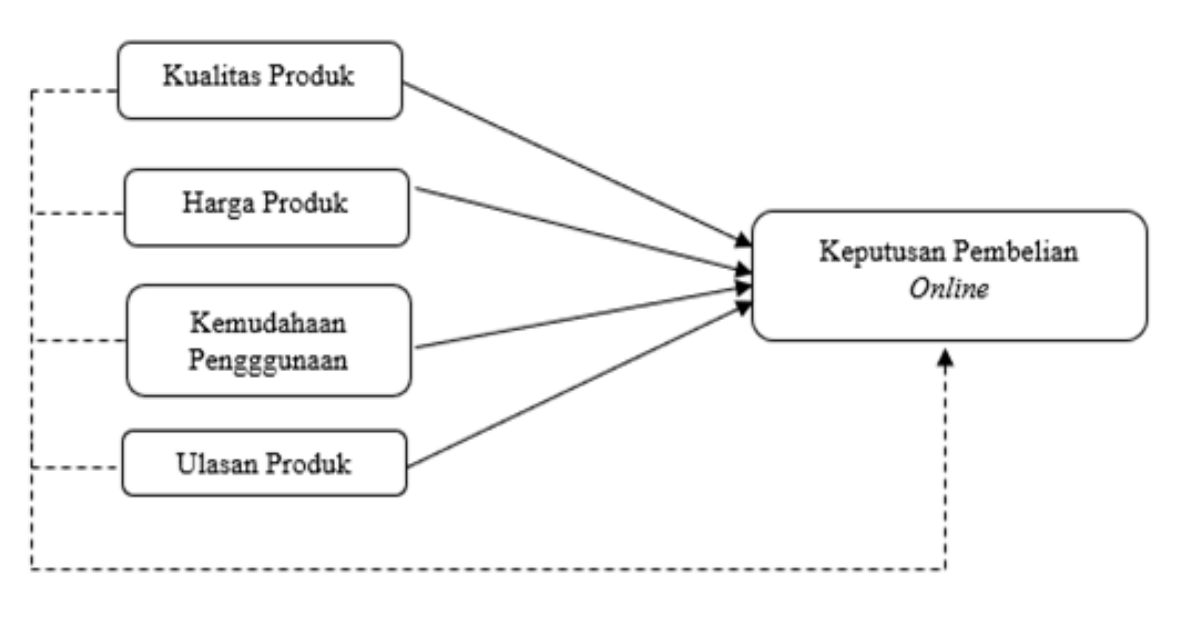

Gambar 1. Kerangka Penelitian

\section{METODE PENELITIAN}

\section{Jenis Penelitian dan Sifat Penelitian}

Metode penelitian adalah cara ilmiah untuk mengumpulkan data untuk tujuan dan kegunaan tertentu. Metode penelitian yang digunakan penulis dalam penelitian ini adalah metode penelitian kuantitatif. Metode penelitian kuantitatif adalah metode penelitian yang didasarkan pada filosofi positivisme. Metode penelitian kuantitatif digunakan untuk meneliti populasi dan sampel tertentu (Sugiyono, 2014).

Menurut Arikunto (2009), dikatakan bahwa jenis penelitian ini adalah penelitian deskriptif kuantitatif. Penelitian deskriptif kuantitatif adalah penelitian yang menggambarkan atau menggambarkan karakteristik suatu keadaan atau objek penelitian yang dilakukan dengan mengumpulkan dan menganalisis data kuantitatif dan uji statistik

\section{Lokasi Penelitian}

Untuk memperoleh data yang dibutuhkan dalam penelitian ini, peneliti melakukan penelitian pada Universitas Muhammadiyah (UMSU), Universitas Negeri Medan (UNIMED) dan Universitas Potensi Utama (UPU) yang dimana populasi dan sampel pada penelitian ini adalah Mahasiswa di Kota Medan. Ketiga Universitas tersebut dianggap sudah mewakili dari lokasi dimana Mahasiswa kota Medan yang menjadi sampel penelitian.

\section{Populasi dan Sampel}

Pada penelitian ini yang menjadi populasi adalah Mahasiswa dari tiga univeristas yang ada di kota Medan yaitu Universitas Muhammadiyah (UMSU), Universitas Negeri Medan (UNIMED) dan Universitas Potensi Utama (UPU). Sampel adalah bagian dari jumlah dan karakteristik yang dimiliki oleh populasi tersebut. Dalam penelitian ini langsung ditentukan jumlah sampel penelitiannya sebesar 100 orang sampel. Sampel penelitiannya adalah Mahasiswa aktif yang melakukan belanja online pada aplikasi/website Shopee yang berasal dari tiga Universitas yang ada di kota Medan yang terbagi menjadi 40 Mahasiswa Universitas Muhammadiyah Sumatera Utara (UMSU), 30 Mahasiswa Universitas Negeri Medan, (UNIMED) dan 30 Mahasiswa Universitas Potensi Utama (UPU). Data penelitian dikumpulkan menggunakan angket yang didisain dengan skala Likert. Di bagian akhir dari kuesioner, terdapat ruang respon terbuka bagi responden untuk mengumpulkan data yang tidak teridentifikasi di bagian tertutup kuesioner.

\section{Teknik Pengumpulan Data}


Untuk dapat mengumpulkan data secara lengkap, dalam penelitian ini digunakan teknik pengumpulan data sebagai berikut:

1. Kuesioner

Dalam penelitian ini, data diperoleh dengan

kuesioner. Kuesioner adalah teknik pengumpulan data yang dilakukan dengan cara menyajikan serangkaian pertanyaan atau kalimat tertulis untuk dijawab oleh responden (Sugiyono, 2014). Kuesioner merupakan teknik pengumpulan data yang efektif jika peneliti mengetahui secara pasti variabel yang akan diukur dan mengetahui apa yang diharapkan dari responden. Skala yang digunakan untuk menyusun kuesioner adalah skala Likert. Skala likert digunakan untuk mengukur sikap, pendapat dan persepsi seseorang atau sekelompok orang tentang fenomena sosial. (Sugiyono, 2014). Dengan skala Likert,

variabel yang akan diukur diubah menjadi indeks variabel. Indikator-indikator ini kemudian digunakan sebagai memasukkan unsur-unsur instrumen baik itu laporan atau kuesioner. Tanggapan untuk setiap item pada skala Likert berkisar dari sangat positif hingga sangat negatif.

Menurut Sugiyono (2014) "untuk keperluan analisis kuantitatif, maka jawaban itu dapat diberi skor dalam skala likert", misalnya:

Tabel 1. Teknik Pengumpulan Suara

\begin{tabular}{|c|l|c|}
\hline No & \multicolumn{1}{|c|}{ Pernyataan } & \multicolumn{1}{|c|}{ Nilai } \\
\hline 1 & Sangat setuju/selalu/sangat positif & diberi skor 5 \\
\hline 2 & Setuju/sering/positif & diberi skor 4 \\
\hline 3 & Ragu-ragu/kadang-kadang/netral & diberi skor 3 \\
\hline 4 & Tidak setuju/hampir tidak pernah/negative & diberi skor 2 \\
\hline 5 & Sangat tidak setuju/tidak pernah/sangat negative & diberi skor 1 \\
\hline
\end{tabular}

\section{Wawancara}

Wawancara digunakan sebagai teknik pengumpulan data, jika peneliti ingin melakukan penelitian pendahuluan untuk mengetahui masalah yang akan diteliti dan juga jika peneliti ingin mengetahui hal-hal dari responden lebih dalam dan jumlah responden yang sedikit (Sugiyono, 2014). Dalam penelitian ini, metode wawancara digunakan untuk penelitian pendahuluan untuk mengetahui masalah yang akan diteliti dan untuk memperluas dan melengkapi data yang dikumpulkan melalui kuesioner.

\section{Jenis dan Sumber Data}

1. Data Primer

Data primer adalah data yang diperoleh melalui atau dari pihak pertama dengan data. Sumber data biasanya menunjukkan keaslian informasi yang terkandung dalam data, namun keaslian data dapat berkurang setelah data diolah dan disajikan oleh sumber primer. (Abdillah, dkk, 2015).

2. Data Sekunder

Data sekunder adalah data yang diperoleh melalui atau

dari pihak kedua yang juga mengetahui atau memiliki data tersebut. Keaslian sumber sekunder dapat dipertanyakan karena data telah diolah/ditafsirkan dan disajikan sesuai dengan kepentingan pemilik data. (Abdillah dkk., 2015). Data tidak secara langsung memberikan data kepada peneliti, misalnya penelitian harus melalui orang lain atau mencari kepustakaan. Data ini dikumpulkan menggunakan studi bibliografi yang dilakukan pada sejumlah buku dan dikumpulkan berdasarkan catatan terkait penelitian, selain menggunakan data yang dikumpulkan oleh peneliti.Penelitian dikumpulkan dari 'Internet. Dalam penelitian ini, data sekunder adalah informasi yang diperoleh dari buku, ulasan penelitian sebelumnya, berita internet, dll.

\section{Uji Validitas dan Reliabilitas}

Sebelum kuesioner penelitian disajikan kepada responden pada saat praktek di lapangan yang dijadikan sampel penelitian, terlebih dahulu harus dilakukan uji validitas dan reliabilitas. Periksa validitas dan reliabilitas minimal 30 responden. Kuesioner yang akan disebarkan sama persis dengan 
yang akan dibagikan kepada responden di lokasi penelitian yang sebenarnya. Pengecekan validitas dan reliabilitas dilakukan dengan menggunakan program software SPSS 23 (Statistical Package for the Social Sciences). Sugiyono (2012), menyatakan bahwa didalam menguji suatu penelitian sangat disarankan agar jumlah responden untuk diuji coba minimal 30 orang.

Sugiyono (2012), menyatakan bahwa instrumen yang valid dan reliabel merupakan syarat mutlak terhadap hasil penelitian yang valid dan reliabel. Suatu kuesioner dinyatakan valid jika butir pertanyaan-pertanyaan dalam kuesioner tersebut cenderung mengungkapkan sesuatu yang akan diukur oleh kuesioner tersebut. Uji validitas dihitung dengan perbandingan rhitung (corrected itemtotal correlation) dengan nilai rtabel. Jika rhitung > rtabel dan nilai yang didapat adalah positif maka butir setiap pertanyaan tersebut dinyatakan valid (Ghozali, 2005). Dengan menggunakan 30 responden maka nilai rtabel dapat diperoleh melalui tabel $\mathrm{r}$ product momment pearson dengan $\mathrm{df}$ $($ degree of freedom $)=\mathrm{N}-2$, maka $\mathrm{df}=30-2=28$. Jadi nilai dari $\mathrm{r}$ tabel adalah 0,361. Berikut adalah hasil uji validitas dari setiap variabelnya :

Tabel 2. Hasil Uji Validitas

\begin{tabular}{|c|c|c|c|}
\hline Item & Corrected Item - Total Corralation & r Tabel & Kesimpulan \\
\hline $\mathrm{X} 1.1$ & 0.793 & 0.361 & VALID \\
\hline $\mathrm{X} 1.2$ & 0.649 & 0.361 & VALID \\
\hline X1.3 & 0.725 & 0.361 & VALID \\
\hline $\mathrm{X} 1.4$ & 0.672 & 0.361 & VALID \\
\hline $\mathrm{X} 1.5$ & 0.651 & 0.361 & VALID \\
\hline $\mathrm{X} 1.6$ & 0.531 & 0.361 & VALID \\
\hline $\mathrm{X} 1.7$ & 0.748 & 0.361 & VALID \\
\hline $\mathrm{X} 2.1$ & 0.814 & 0.361 & VALID \\
\hline $\mathrm{X} 2.2$ & 0.495 & 0.361 & VALID \\
\hline $\mathrm{X} 2.3$ & 0.583 & 0.361 & VALID \\
\hline $\mathrm{X} 2.4$ & 0.446 & 0.361 & VALID \\
\hline $\mathrm{X} 2.5$ & 0.814 & 0.361 & VALID \\
\hline $\mathrm{X} 3.1$ & 0.495 & 0.361 & VALID \\
\hline $\mathrm{X} 3.2$ & 0.861 & 0.361 & VALID \\
\hline $\mathrm{X} 3.3$ & 0.839 & 0.361 & VALID \\
\hline $\mathrm{X} 3.4$ & 0.798 & 0.361 & VALID \\
\hline X3.5 & 0.849 & 0.361 & VALID \\
\hline X3.6 & 0.725 & 0.361 & VALID \\
\hline $\mathrm{X} 4.1$ & 0.672 & 0.361 & VALID \\
\hline $\mathrm{X} 4.2$ & 0.651 & 0.361 & VALID \\
\hline $\mathrm{X} 4.3$ & 0.631 & 0.361 & VALID \\
\hline X4.4 & 0.748 & 0.361 & VALID \\
\hline $\mathrm{X} 4.5$ & 0.697 & 0.361 & VALID \\
\hline $\mathrm{X} 4.6$ & 0.814 & 0.361 & VALID \\
\hline Y1.1 & 0.695 & 0.361 & VALID \\
\hline $\mathrm{Y} 1.2$ & 0.783 & 0.361 & VALID \\
\hline Y1.3 & 0.546 & 0.361 & VALID \\
\hline $\mathrm{Y} 1.4$ & 0.648 & 0.361 & VALID \\
\hline
\end{tabular}


\begin{tabular}{|l|l|l|l|} 
Y1.5 & 0.831 & 0.361 & VALID \\
\hline
\end{tabular} Sumber:Hasil pengelolaan data SPSS (2019)

Uji reliabilitas dapat dilakukan pada semua pertanyaan untuk lebih dari satu variabel secara bersamaan, tetapi sebaiknya uji reliabilitas dilakukan pada setiap variabel pada lembar kerja yang berbeda sehingga dapat diketahui struktur variabelnya. Suatu kuesioner dinyatakan reliabel atau dapat dipercaya jika jawaban seseorang terhadap suatu pertanyaan/pernyataan konsisten dan stabil dari waktu ke waktu. Keandalan suatu struktur variabel dikatakan baik jika memiliki nilai Cronbach Alpha $>0,6$. Jika alpha 0,6 berarti cukup percaya diri (sufficient confidence), jika alpha 0,80 menunjukkan bahwa semua item reliabel dan semua tes selalu memiliki kepercayaan tinggi atau ada yang menjelaskannya sebagai berikut :

1. Jika alpha $>0,90$ maka reliabilitas sempurna.

2. Jika alpha antara $0,60-0,90$ maka reliabilitas tinggi.

3. Jika alpha antara $0,50-0,60$ maka reliabilitas moderat.

4. Jika alpha $<0,50$ maka reliabilitas rendah.

Apabila hasil pengujian menunjukkan reliabilitas yang rendah maka butir-butir pertanyaan dalam kuisioner harus diperbaiki mutunya karena dinilai tidak mampu menghasilkan data yang konsisten. Berikut adalah hasil uji reliabilitas setiap variabel dalam penelitian ini:

Tabel 3. Hasil Uji Reliabilitas

\begin{tabular}{|c|c|c|}
\hline Item & Cronbach's Alph & Kesimpulan \\
\hline $\mathrm{X} 1$ & 0.899 & RELIABEL \\
\hline $\mathrm{X} 2$ & 0.814 & RELIABEL \\
\hline $\mathrm{X} 3$ & 0.834 & RELIABEL \\
\hline $\mathrm{X} 4$ & 0.875 & RELIABEL \\
\hline $\mathrm{Y}$ & 0.669 & RELIABEL \\
\hline
\end{tabular}

Sumber: Hasil pengelolaan data SPSS (2018)

\section{Teknik Uji Analisis Data}

Sugiyono (2012), analisis data merupakan bagian dari proses telaah data yang hasilnya digunakan sebagai bukti yang cukup untuk mencapai kesimpulan penelitian. Analisis data adalah kegiatan setelah mengumpulkan data dari semua sumber dengan menggunakan statistik. Sugiyono (2012), statistik deskriptif adalah statistik yang digunakan untuk menganalisis data dengan cara mendeskripsikan atau menggambarkan data yang telah dikumpulkan apa adanya tanpa bermaksud menarik kesimpulan yang berlaku untuk masyarakat umum. Dalam penelitian ini, statistik deskriptif yang digunakan untuk menginterpretasikan hasil pencarian adalah tabel distribusi frekuensi, nilai mean, nilai maksimum, dan nilai minimum

1. Uji Normalitas

Uji normalitas dimaksudkan untuk mengetahui apakah sebaran data mengikuti atau mendekati sebaran normal, yaitu sebaran data mengikuti bel dan sebaran data tidak miring ke kiri atau ke kanan. Uji normalitas dilakukan dengan menggunakan metode Kolmogorov Smirnov. Menggunakan taraf signifikan 5\% (0,05) maka jika nilai Asymp.Sig. $(2-$ tailed $)$ di atas nilai signifikan $10 \%$ artinya variabel residual berdistribusi normal.

2. Uji Heteroskedastisitas

Uji heteroskedastisitas bertujuan untuk menguji apakah suatu kelompok memiliki varians yang sama di antara anggotanya. Artinya, jika varians variabel independen adalah konstan (sama) untuk suatu nilai tertentu, maka variabel dependen disebut varians variabel. Sedangkan varians variabel diuji menggunakan uji Glejser dengan pengambilan keputusan jika variabel independen berpengaruh signifikan secara statistik terhadap variabel dependen, hal tersebut 
merupakan indikasi varians variabel. Jika probabilitas secara signifikan lebih besar dari tingkat kepercayaan $5 \%(0,05)$, dapat disimpulkan bahwa model regresi tidak mengarah adanya heteroskedastisitas.

3. Uji Multikolinearitas

Multikolinearitas berarti terdapat hubungan linier yang pasti atau sempurna antara beberapa atau semua variabel yang menjelaskan model regresi. Untuk mendeteksi ada atau tidaknya multikolinearitas dapat dilakukan dengan cara melihat nilai toleransi variabel dan Variance Inflation Factor (VIF) dengan membandingkan sebagai berikut:

a. $\mathrm{VIF}<5$ maka tidak terdapat multikolinearitas

b. VIF $>5$ maka tidak terdapat multikolinearitas

\section{HASIL DAN PEMBAHASAN}

Variabel yang digunakan dalam penelitian ini adalah Perilaku Nasabah, Loyalitas Nasabah, dan Keputusan Pengambilan Kredit. Seluruh variabel tersebut di uji pengaruhnya masing-masing untuk mendapatkan hasil kesimpulannya lewat beberapa tahap proses pengujian.

\section{Uji Normalitas}

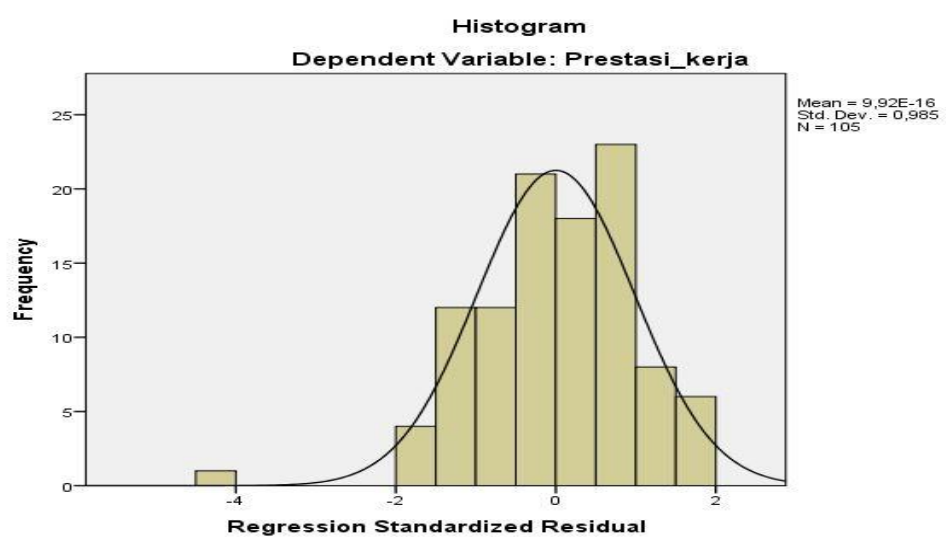

Gambar 2. Hasil Uji Normalitas

Berdasarkan gambar tersebut dapat dilihat bahwa variabel distribusi memberikan hasil yang normal, yang dapat diwakili oleh data membentuk gambar menyerupai lonceng. Data variabel terdistribusi yang disajikan menunjukkan bahwa hasil uji statistik tidak melanggar asumsi yang berarti hasil tersebut valid. Maksud dari uji normal adalah untuk menguji model regresi distribusi data berikut atau mendekati dari distribusi normal, yaitu data berdistribusi berbentuk lonceng. Jika asumsi ini dilanggar, uji statistik akan menjadi tidak valid.

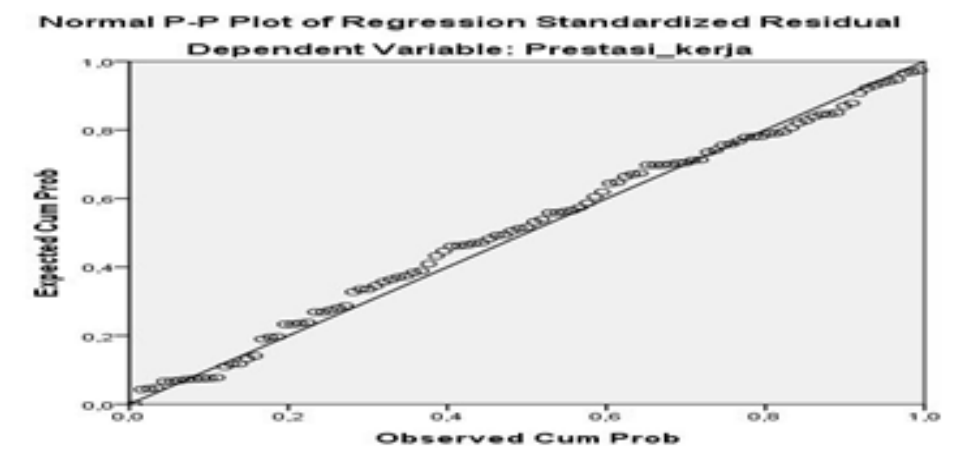

Gambar 3. Hasil Uji Normalitas P-Plot 
Berdasarkan tersebut dapat diketahui bahwa variabel berdistribusi menunjukkan hasil yang normal,hal ini dapat ditunjukkan oleh data tersebut yang tidak melenceng ke kiri atau ke kanan, sedangkan pada gambar dapat juga terlihat titik yang mengikuti data di sepanjang garis diagonal, hal ini berarti databerdistribusi normal.

\section{Uji Kolmogorov-Smirnov Test}

Tabel 4. Hasil Uji Kolmogorov-Smirnov Test

\begin{tabular}{|ll|r|}
\hline & & $\begin{array}{c}\text { Unstandardiz } \\
\text { ed Residual }\end{array}$ \\
\hline $\mathrm{N}$ & Mean & $\begin{array}{r}105 \\
\text { Normal Parameters a,b }\end{array}$ \\
Most Extreme Differences & Std. Deviation &, 0000000 \\
& Absolute & 1,11505224 \\
& Negative &, 060 \\
Test Statistic & Positive &, 042 \\
Asymp. Sig. (2-tailed) & &,- 060 \\
\hline
\end{tabular}

Berdasarkan Tabel tersebut terlihat bahwa nilai Asymp.Sig. (2-tailed) adalah 0.200 ini berarti nilainya diatas nilai signifikan 5\% (0,05). Dengan kata lain variabel tersebut berdistribusi normal.

\section{Uji Heterokedastisitas}

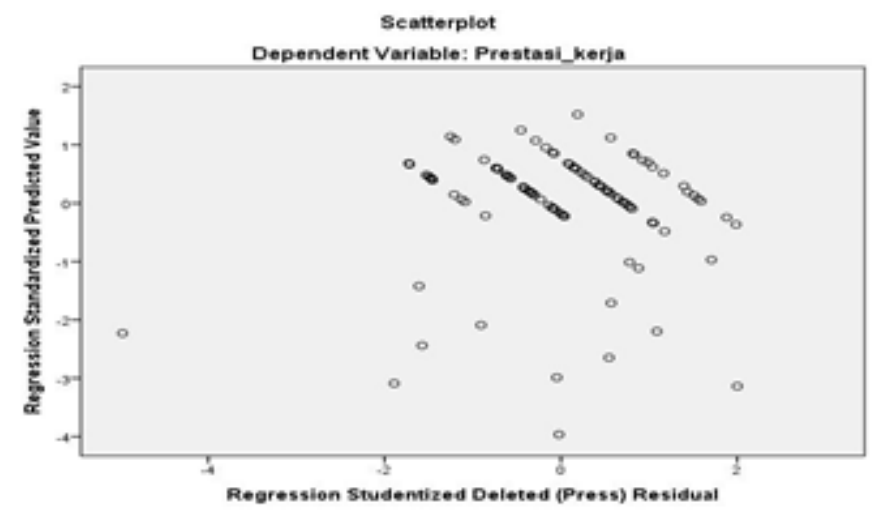

Gambar 4. Hasil Uji Heterokedastisitas

Berdasarkan histogram data yang diolah dari hasil perhitungan SPSS pada gambar, terlihat bahwa sebaran data tidak terkumpul dalam satu sudut/bagian saja, tetapi sebaran data mencakup seluruh bagian. Oleh karena itu, dapat disimpulkan bahwa tidak ada varians variabel dalam data, sehingga dapat dikatakan bahwa data penelitian homogen. Model regresi yang baik adalah model dengan atau tidak terjadi gejala heteroskedastisitas.

\section{Uji Multikolinearitas}

Tabel 5. Hasil Uji Multikolinearitas

\begin{tabular}{|c|c|c|c|c|c|c|c|}
\hline \multirow{2}{*}{ Model } & \multicolumn{2}{|c|}{ Unstandart Coefficients } & \multirow{2}{*}{$\begin{array}{c}\begin{array}{c}\text { Standardized } \\
\text { Coefficients }\end{array} \\
\text { Beta }\end{array}$} & \multirow{2}{*}{$\mathbf{t}$} & \multirow{2}{*}{ Sig } & \multicolumn{2}{|c|}{ Collinearity Statistics } \\
\hline & B & Std.Error & & & & Tolerance & VIF \\
\hline $1 \quad$ (Constant) & 1,371 & 1,332 & & 1,029 & ,306 & & \\
\hline
\end{tabular}


Wisnu Rayhan Adhitya, Analisis Faktor-Faktor Yang Mempengaruhi... 157

\begin{tabular}{|l|r|r|r|r|r|r|r|} 
Kualitas_produk &, 126 &, 061 &, 237 & 2,052 &, 043 &, 395 & 2,543 \\
Harga_produk &, 020 &, 071 &, 028 & 2,287 &, 075 &, 543 & 1,843 \\
Kemudahan_berbelanja &, 283 &, 062 &, 478 & 4,672 &, 000 &, 479 & 2,088 \\
Ulasan_produk &, 175 &, 044 &, 350 & 3,513 &, 017 &, 421 & 2,317 \\
\hline
\end{tabular}

1. Nilai VIF dari variabel kualitas produk,harga produk, kemudahan berbelanja dan ulasan produk lebih kecil atau dibawah 5 (VIF < 5), iniberarti tidak terdapat multikolinearitas antar independen dalam model regresi.

2. Nilai Tolerance dari variabel kualitas produk,harga produk, kemudahan berbelanja dan ulasan produk lebih besar dari 0,1 . Ini berartitidak terdapat multikolinearitas antar variabel independen dalam model regresi.

\section{Analisis Regresi Linier Berganda}

Untuk mengetahui pengaruh atau hubungan variabel bebas $\left(\mathrm{X}_{1}, \mathrm{X}_{2}, \mathrm{X}_{3}, \mathrm{X}_{4}\right)$ berupa variabel variabel kualitas produk, harga produk, kemudahan berbelanja dan ulasan produk dan variabel terikat (Y) berupa Keputusan Pembelian online mahasiswa di kota Medan pada aplikasi Shopee, maka untuk memperoleh hasil yang lebih akurat, penulis menggunakan bantuan program software SPSS (statistik product and service solution) versi23,0 dari tabel coefficient maka dihasilkan output sebagai berikut :

Tabel 6. Hasil Uji Regresi Linear Berganda

\begin{tabular}{|l|l|r|r|r|r|r|}
\hline \multicolumn{2}{|l|}{} & \multicolumn{2}{|c|}{$\begin{array}{c}\text { Unstandardizerd } \\
\text { Coefficients }\end{array}$} & $\begin{array}{c}\text { Standardizerd } \\
\text { Coefficients }\end{array}$ & & \\
\cline { 3 - 8 } \multicolumn{2}{|l|}{ Model } & \multicolumn{1}{c|}{ B } & Std. Error & \multicolumn{1}{c|}{ Beta } & \multicolumn{1}{c|}{ t } & \multicolumn{1}{c|}{ sig. } \\
\hline 1 & & & & & \\
& (constant) & 1.572 & .280 & & 5.605 & .000 \\
\cline { 2 - 7 } & Perilaku Nasabah & .069 & .071 & .077 & .974 & .333 \\
\cline { 2 - 8 } & Loyalitas Nasabah & .014 & .025 & .045 & .552 & .582 \\
\hline
\end{tabular}

a. Dependent variabel: keputusan

Berdasarkan hasil pengolahan data seperti terlihat pada kolom Unstandardized Coeffisien bagian Bdiperoleh persamaan regresi linear berganda sebagai berikut :

$\mathrm{Y}=1,371+0,126 \mathrm{X} 1+0,020 \mathrm{X} 2+0,283 \mathrm{X} 3+0,175 \mathrm{X} 4+\mathrm{e}$

Berdasarkan persamaan tersebut dapat digambarkan sebagai berikut :

1. Konstanta (a) =1,371. Hasil ini memiliki arti bahwa kualitas produk, harga produk, kemudahan berbelanja dan ulasan produk dianggap konstan maka keputusan pembelian online mahasiswa di kota Medan pada aplikasi Shopee (Y) sebesar 1,371.

2. Koefisien $\mathrm{X} 1=0,126$. Variabel kualitas produk terhadap keputusan pembelian online mahasiswa di kota Medan pada aplikasi Shopee dengan koefisien regresi sebesar 0,126. Ini memiliki arti bahwa setiap terjadi peningkatan variabel kualitas produk sebesar 1 satuan, maka keputusan pembelian online akan meningkat sebesar 0,126.

3. Koefisien $\mathrm{X} 2=0,020$. Variabel harga produk terhadap keputusan pembelian online mahasiswa di kota Medan pada aplikasi Shopee dengan koefisien regresi sebesar 0,020. Ini memiliki arti bahwa setiap terjadi peningkatan variabel harga produk sebesar 1 satuan, maka keputusan pembelian online akan meningkat sebesar 0,020 .

4. Koefisien $\mathrm{X} 3=0,283$. Variabel kemudahan berbelanja terhadap keputusan pembelian online mahasiswa di kota Medan pada aplikasi Shopee dengan koefisien regresi sebesar 0,283. Ini memiliki arti bahwa setiap terjadi peningkatan variabel kemudahan berbelanja sebesar 1 satuan, maka keputusan pembelian online akan meningkat sebesar 0,283.

5. Koefisien $\mathrm{X} 4=0,175$. Variabel ulasan produk terhadap keputusan pembelian online mahasiswa di kota Medan pada aplikasi Shopee dengan koefisien regresi sebesar 0,175. Ini 
memiliki arti bahwa setiap terjadi peningkatan variabel ulasan produk sebesar 1 satuan, maka keputusan pembelian online akan meningkat sebesar 0,175

\section{Uji Koefisien Determinasi $\left(\mathbf{R}^{2}\right)$}

Tujuan uji koefisien determinasi $\left(\mathrm{R}^{2}\right)$ adalah untuk mengetahui sejauh mana kemampuan variabel bebas dalam menjelaskan variabel terikat. Pada output SPSS, koefisien determinasi ada pada tabel model dan tertulis $R$ Square. Namun untuk regresi linear berganda sebaiknya menggunakan $R$ Square yangsudah disesuaikan atau tertulis Adjusted $R$ Square, karena disesuaikan dengan jumlah variabel bebas dalampenelitian. Nilai $R$ Square dikatakan baik jika di atas 0,5 karena nilai $R$ Square berkisar antar 0 sampai 1.

Tabel 7. Hasil Uji Koefisien Determinasi

\begin{tabular}{|l|c|r|r|r|r|}
\hline Model & R & R Square & $\begin{array}{c}\text { Adjusted R } \\
\text { Square }\end{array}$ & $\begin{array}{r}\text { Std. Error of } \\
\text { the Estimate }\end{array}$ & $\begin{array}{r}\text { Durbin- } \\
\text { Watson }\end{array}$ \\
\hline 1 &, $749^{\mathrm{a}}$ &, 470 &, 385 & 1,071 & 2,168 \\
\hline
\end{tabular}

Berdasarkan hasil pengujian identifikasi determinasi pada Tabel 4.13 menunjukkan bahwa :

1. $\mathrm{R}=0,749$ artinya hubungan (relation) antara kualitas produk, harga produk, kemudahan berbelanja dan ulasan produk terhadap keputusan pembelian online mahasiswa di Kota Medan pada aplikasi Shopee adalah 74, 9\% yang artinya memiliki hubungan yang erat. Semakin besar R, semakin kuat hubungannya.

2. Adjusted R Square sebesar 0,385 berarti 38,5\% faktor-faktor yang mempengaruhi keputusan pembelian online mahasiswa di kota Medan pada aplikasi Shopee dapat dijelaskan oleh disiplin kerja, kompensasi dan lingkungan kerja. Sedangkan sisanya 38,5\% dapat dijelaskan oleh faktor-faktor lain yang tidak diteliti oleh penelitian ini.

3. Standart Error of Estimated artinya mengukur variasi dari nilai yang diprediksi. Standart error of Estimated juga bisa disebut standar deviasi. Dari tabel di atas Standart Error of Estimated adalah 1,071. Semakin kecil standar deviasi berarti model semakin baik.

\section{Uji Hipotesis}

Tabel 8. Uji Signifikan Parsial (Uji-t)

\begin{tabular}{|c|c|c|c|c|c|c|c|c|}
\hline \multirow{2}{*}{\multicolumn{2}{|c|}{ Model }} & \multicolumn{2}{|c|}{ Unstandart Coefficients } & \multirow{2}{*}{$\begin{array}{c}\text { Standardized } \\
\text { Coefficients }\end{array}$} & \multirow{2}{*}{$\mathbf{t}$} & \multirow{2}{*}{ Sig } & \multicolumn{2}{|c|}{ Collinearity Statistics } \\
\hline & & B & Std.Error & & & & Tolerance & VIF \\
\hline \multirow[t]{5}{*}{1} & (Constant) & 1,371 & 1,332 & & 1,029 & ,306 & & \\
\hline & Kualitas_produk & , 126 & 061 & 237 & 2,052 &, 043 & 395 & 2,543 \\
\hline & Harga_produk & 020 & 071 & 028 & 2,287 &, 075 &, 543 & 1,843 \\
\hline & Kemudahan_berbelanja & ,283 & 062 & , 478 & 4,672 &, 000 & ,479 & 2,088 \\
\hline & Ulasan_produk & , 175 & 044 &, 350 & 3,513 &, 017 & ,421 & 2,317 \\
\hline
\end{tabular}

1. Nilai thitung variabel kualitas produk (X1) sebesar 2,052 berpengaruh secara positif dan signifikan sebesar 0,043. Hipotesis Ho ditolak karena thitung > ttabel $(2,052>1,983)$ yang artinya jika ditingkatkan variabel kualitas produk (X1) akan meningkatkan keputusan pembelian online (Y).

2. Nilai thitung harga produk (X2) sebesar 0,287 berpengaruh secara positif dan signifikan sebesar 0,075 . Hipotesis Ho ditolak karena thitung $>\operatorname{ttabel}(0,287>1,983)$ yang artinya jika ditingkatkan variabel harga produk (X2) akan meningkatkan keputusan pembelian online (Y).

3. Nilai thitung variabel kemudahan berbelanja (X3) sebesar 4,672 berpengaruh secara positif dan 
signifikan sebesar 0,000. Hipotesis Ho ditolak karena thitung > ttabel $(4,672>1,983)$ yang artinya jika ditingkatkan kemudahan berbelanja (X3) maka meningkatkan keputusan pembelian online (Y).

4. Nilai thitung variabel ulasan produk (X4) sebesar 3,513 berpengaruh secara positif dan signifikan sebesar 0,017. Hipotesis Ho ditolak karena thitung > ttabel $(3,513>1,983)$ yang artinya jika ditingkatkan ulasan produk (X3) maka meningkatkan keputusan pembelian online (Y).

5. Konstanta sebesar 1,029 artinya walaupun variabel bebas bernilai nol maka prestasi kerja tetap sebesar 1,029 .

6. Berdasarkan hasil output uji t maka rumus persamaan regresinya adalah :

$$
\begin{gathered}
\mathrm{Y}=\mathrm{a}+\mathrm{b} 1 \mathrm{X} 1+\mathrm{b} 2 \mathrm{X} 2+\mathrm{b} 3 \mathrm{X} 3+\mathrm{b} 4 \mathrm{X} 4+\mathrm{e} \\
\mathrm{Y}=1,371+0,126 \mathrm{X} 1+0,020 \mathrm{X} 2+0,283 \mathrm{X} 3+0,175 \mathrm{X} 4+\mathrm{e}
\end{gathered}
$$

\section{Uji Signifikan Simultan (Uji-F)}

Tabel 9. Hasil Uji Signifikan Simultan

\begin{tabular}{|ll|r|r|r|c|c|}
\hline \multirow{2}{*}{ Model } & $\begin{array}{r}\text { Sum of } \\
\text { Squares }\end{array}$ & Df & Mean Square & F & Sig \\
\hline 1 & Regression & 158,055 & 4 & 39,514 & 25,564 &, $000^{\mathrm{b}}$ \\
& Residual & 674,695 & 95 & 7,102 & & \\
& Total & 832,750 & 99 & & & \\
\hline
\end{tabular}

1. Hasil pengujian ANOVA dengan menggunakan uji $\mathrm{F}$ pada Tabel diatas memperlihatkan nilai Fhitung sebesar 25,5641 dengan Sig 0,000. Dengan mencari pada Tabel F, dengan dfl=4 dan df2=95, diperoleh nilai Ftabel sebesar 2,46. Dengan kondisi Fhitung lebih besar daripada Ftabel $(25,564>2,46)$ dengan nilai Sig 0,000 yang berarti lebih kecil dari alpha $(0,000<0.05)$, maka kesimpulan dapat diambil adalah menolak $\mathrm{H} 0$ yang berarti bahwa variabel bebas yang terdiri dari kualitas produk (X1), harga produk (X2), kemudahan berbelanja (X3) dan ulasan produk (X4) secara bersama-sama atau simultan memiliki pengaruh yang positif dan signifikan terhadap variabel terikat (Y) berupa keputusan pembelian online mahasiswa di kota Medan pada aplikasi Shopee.

2. Kolom pertama uji ANOVA yaitu kolom regresi merupakan penjumlahan kuadrat dari varians yang dihasilkan oleh model persamaan regresi yaitu 158.055 sedangkan kolom kedua yaitu residual yang merupakan penjumlahan kuadrat dari varians tidak dihasilkan dari model persamaan regresi yaitu 129.308 .

\section{KESIMPULAN}

Berdasarkan hasil pengujian uji $\mathrm{f}$ bahwa variabel bebas yang terdiri dari kualitas produk (X1), harga produk (X2), kemudahan berbelanja (X3) dan ulasan produk (X4) secara bersamasama atau simultan berpengaruh positif dan signifikan terhadap variabel terikat (Y) berupa keputusan pembelian online mahasiswa di kota Medan pada aplikasi Shopee.

Berdasarkan hasil pengujian uji t bahwa variabel kualitas produk (X1) secara parsial berpengaruh positif dan signifikan yang artinya jika ditingkatkan variabel disiplin kerja (X1) akan meningkatkan keputusan pembelian online mahasiswa di kota Medan pada aplikasi Shopee.

Berdasarkan hasil pengujian uji t bahwa variabel harga produk (X2) secara parsial berpengaruh positif dan signifikan yang artinya jika ditingkatkan harga produk (X2) akan meningkatkan keputusan pembelian online mahasiswa di kota Medan pada aplikasi Shopee.

Berdasarkan hasil pengujian uji t bahwa variabel kemudahan berbelanja (X3) secara 
parsial berpengaruh positif dan signifikan yang artinya jika ditingkatlan variabel kemudahan berbelanja (X3) akan meningkatkan keputusan pembelian online mahasiswa di kota Medan pada aplikasi Shopee.

Berdasarkan hasil pengujian uji t bahwa variabel ulasan produk (X4) secara parsial berpengaruh positif dan signifikan yang artinya jika ditingkatlan variabel ulasan produk (X4) akan meningkatkan keputusan pembelian online mahasiswa di kota Medan pada aplikasi Shopee

\section{DAFTAR PUSTAKA}

[1] Abdurrahmat, Fathoni, 2006. Organisasi dan Manajemen Sumber Daya Manusia. Jakarta: Asdi Mahasatya.

[2] Arikunto. 2009. Manajemen Penelitian. Jakarta: Rineka Cipta.

[3] Ghozali, Imam. 2005. Aplikasi Analisis Multivariate Dengan Program SPSS. Semarang: Badan Penerbit Universitas Diponegoro.

[4] Gie Liang. 2012. Sumber Daya Manusia. Jakarta: Rineka Cipta.

[5] Hasibuan, Malayu S.P. 2005. Manajemen Sumber Daya Manusia. Jakarta: PT. Bumi Aksara.

[6] Hasibuan, Malayu S.P. 2009. Manajemen Sumber Daya Manusia. Cetakan keenam. Jakarta: PT. Bumi Aksara.

[7] Hartatik Puji Indah. 2014. Mengembangkan SDM. Jogjakarta: Laksana.

[8] Handoko T.Hani. 2012. Manajemen Personalia dengan Sumber Daya Manusia. Yohyakarta: BPEE.

[9] Herlina, Haturiningsih, dkk. 2014. Faktor-Faktor yang Mempengaruhi Prestasi Kerja. Jurnal Administrative Reform. Volume 2. Nomor 4. ISSN 2338-7637.

[10] Husein Umar. 2008. Metode Penelitian Untuk Skripsi dan Thesis. Jakarta: Raja Grafindo Persada.

[11] Ishak, Hendri Tanjung dan Arek. 2013. Manajemen Sumber Daya Manusia. Universitas Trisakti: Jakarta.

[12] Kadarisman. 2014. Manjemen Kompensasi. Cetakan Kedua. Jakarta: Rajawali.

[13] Mangkunegara, A.A. Anwar Prabu. 2005. Evaluasi Kinerja SDM. Bandung: PT. Refika Aditama.

[14] Mangkunegara, A.A. Anwar Prabu. 2011. Manajemen Sumber Daya Manusia. Jakarta: PT. Bumi Aksara.

[15] Mangkunegara, A.A. Anwar Prabu. 2005. Manajemen Sumber Daya Manusia Perusahaan. Cetakan Ketiga. Bandung: PT. Remaja Rosdakarya.

[16] Mangkunegara, A.A. Anwar Prabu. 2009. Manajemen Sumber Daya Manusia Perusahaan. 
Cetakan Ketiga. Bandung: PT. Remaja Rosdakarya.

[17] Ma'arif Syamsul, Kartika Lindawati. 2012. Manajemen Kinerja Sumber Daya Manusia. Cetakan Pertama. Bogor: IPB.

[18] Marwansyah, Mukaram. 2012. Manajemen Sumber Daya Manusia. Bandung: Pusat Penerbit Administrasi Niaga Politeknik Negeri Bandung.

[19] Munandar, Kartika, dkk. 2014. Pengantar Manajemen. Bogor: IPB.

[20] Nawawi Ismail. 2013. Budaya Organisasi Kepemimpinan dan Kinerja. Cetakan Perttama. Jakarta: Kencana.

[21] Niti Seminto, Alex. S. 2011. Manajemen Personalia. Ghalia: Bandung.

[22] Priyatno, Duwi. 2010. Paham Analisa Data Dengan SPSS. Yogyakarta: Mediakom.

[23] Samsuddin, Sadili. 2006. Manajemen Sumber Daya Manusia. Bandung: Pustaka Setia.

[24] Sarwono Jonathan. 2017. Mengenal Prosedur-Prosedur Populer Dalam SPSS 23. Jakarta: PT. Alex Media Komputindo.

[25] Sastrohadiwiryo Siswanto. 2012. Manajemen Tenaga Kerja Indonesia. Jakarta: PT. Bumi Aksara.

[26] Sedamayanti, 2012. Manajemen Sumber Daya Manusia. Bandung: Refika Aditama.

[27] Sutrisno edy. 2009. Manajemen Sumber Daya ManusiaI. Jakarta: Kencana.

[28] Supomo, Bambang, dkk. 2006. Metode Penelitian Bisnis Untuk Akuntansi Dan Manajemen. Cetakan kedua. Yogyakarta: BPFE.

[29] Sugiyono. 2014. Metode Penelitian Kuantitatif Kualitatif Dan R\&D. Bandung: Alfabeta.

[30] Ulfatin Nurul, Triwiyanto Teguh. 2016. Manajemen Sumber Daya Manusia Bidang Pendidikan. Cetakan Pertama. Jakarta: PT. Raja Grafindo Persada.

[31] Wukir. 2013. Manajemen Sumber Daya Manusia Dalam Organisasi Sekolah. Cetakan I. Yogyakarta: Multi Presindo.

[32] Widodo Suparno, Eko. 2015. Manajemen Pengembangan Sumber Daya Manusia.Yogyakarta: Pustaka Pelajar.

[33] Yani. 2012. Manajemen Sumber Daya Manusia. Jakarta: Mitra Wacana Media. 